\title{
A COMPARATIVE RADIOGRAPHIC STUDY OF RHEUMATOID ARTHRITIS AND ARTHRITIS ASSOCIATED WITH PSORIASIS
}

\author{
BY \\ V. WRIGHT \\ University Department of Clinical Medicine, General Infirmary, Leeds
}

\begin{abstract}
Attention was focused on the association of psoriasis and arthritis by Alibert (1822), and the first detailed examination of the relation between the two was that of Bourdillon (1888). Since then there has been much interest in and argument about psoriatic arthritis. Definitions of the condition have been various: an arthritis confined to the distal interphalangeal joints associated with psoriasis (Bauer, Bennett, and Zeller, 1941), an atypical arthritis associated with atypical psoriasis (Dawson, 1937), and a form of atrophic arthritis associated with psoriasis exhibiting a reasonable amount of synchronous activity as evidenced by remissions and relapses in arthritis and cutaneous manifestations (Epstein, 1939; Jeghers and Robinson, 1937;
\end{abstract} Lane and Crawford, 1937). Other authors have denied its existence as a separate entity, feeling that it represented the coincidence of two common diseases, psoriasis and rheumatoid arthritis (Brocq, 1910; Gribble, 1955; Margolis, 1941). Recently, workers with the Rose-Waaler differential agglutination test (D.A.T.), which is positive in about 80 per cent. of patients with rheumatoid arthritis (Greenbury, Hill, Spalding Smith, and Good, 1956; Brit. med. J., 1956; Wright, 1957c), have noted that, in those patients who had psoriasis with atrophic arthritis, the test was usually negative (Ball, 1952; Coste, 1958; Coste and others, 1958; de Forest, Mucci, and Boisvert, 1956; Jacobson, Kammerer, Wolf, Epstein, and Heller, 1956; Ziff, 1957), as was the latex-fixation test (Reed and Becker, 1960). From a previous study of 39 patients with psoriasis and arthritis, it was suggested that those patients who had a negative D.A.T. either had rheumatoid arthritis modified by the presence of psoriasis, or (more likely) were suffering from a different and distinct condition (Wright, 1956, 1957b).

Radiographically, the interest in this condition is reflected by the recent publication of single cases and small series (Carrier, 1958; Meaney and Hays, 1957; Reed and Becker, 1960). Good reviews of the subject have been published by Fawcitt (1950) and Sherman (1952), but surveys of the general field of psoriasis and joint disease have been few. A retrospective analysis has been done at the Mayo Clinic, but no prospective study was undertaken (Avila, Pugh, Slocumb, and Winkelmann, 1960). In a previous report (Wright, 1957a), the radiographic features of psoriatic arthritis were discussed, but the number of patients was too small for statistical analysis and no control series of patients with uncomplicated rheumatoid arthritis was studied. The series has therefore been extended and comparison made with patients with rheumatoid arthritis.

\section{Material and Methods}

157 patients with psoriasis and various rheumatic complaints have been considered, of whom 121 had erosive arthritis. 91 of the patients with psoriasis and erosive arthritis were paired with patients of the same sex and age who had uncomplicated rheumatoid arthritis of the same duration and had a positive D.A.T. Radiographs of the hands, feet, and sacro-iliac joints were taken. The films of the sacro-iliac joints in four patients with psoriatic arthritis and one with rheumatoid arthritis, and of the feet in two patients with psoriatic arthritis and one with rheumatoid arthritis were not available for study. The films were read without the name or diagnosis of the patients being known.

The D.A.T. was done by a modification of existing techniques (Heller, Kolodny, Lepow, Jacobson, Rivera, and Marks, 1955; Rose, Ragan, Pearce, and Lipman, 1948; Waaler, 1940) introduced by Greenbury and others (1956). 


\section{General Review of Results}

The composition of the series is shown in Table I. Patients with osteo-arthritis, gout, rheumatic fever, and muscular rheumatism showed no atypical clinical or radiographic features and their association seemed fortuitous.

TABLE I

COMPOSITION OF SERIES WITH PSORIASIS AND RHEUMATIC COMPLAINTS

\begin{tabular}{|c|c|c|c|}
\hline \multirow{2}{*}{ Diagnosis } & & Sex & \\
\hline & Male & Female & Total \\
\hline $\begin{array}{l}\text { Erosive Arthritis } \\
\text { Osteo-arthritis .. } \\
\text { Gout . . } \\
\text { Rheumatic Fever } \\
\text { Muscular Rheumatism }\end{array}$ & $\begin{array}{r}42 \\
9 \\
2 \\
2 \\
5\end{array}$ & $\begin{array}{r}79 \\
14 \\
0 \\
0 \\
4\end{array}$ & $\begin{array}{r}121 \\
23 \\
2 \\
2 \\
9\end{array}$ \\
\hline Total & 59 & 95 & 157 \\
\hline
\end{tabular}

Of the 121 patients with psoriasis and erosive arthritis, eighteen had a positive D.A.T. The clinical findings in these were the same as in the group with uncomplicated rheumatoid arthritis. Subcutaneous nodules were present in four, an incidence similar to that in rheumatoid arthritis both in this and other series (Bauer, 1939; Short, Bauer, and Reynolds, 1957). There was no significant difference in the radiographic features of the arthritis compared with uncomplicated rheumatoid arthritis, and these patients were considered as examples of coincidental rheumatoid arthritis.

The clinical picture of 103 patients (33 men, 70 women) with psoriasis and erosive arthritis with a negative D.A.T. differed from uncomplicated rheumatoid arthritis and has been described elsewhere (Wright, 1959). There were differences also in the radiographic appearances. The term "psori- $\frac{\vec{T}}{\widehat{0}}$ atic arthritis" has been used for patients with psoriasis and erosive arthritis with a negative D.A.T. In this analysis the group with psoriatic on arthritis has been compared with uncomplicated rheumatoid arthritis and coincidental rheumatoid $\stackrel{\infty}{+}$ arthritis and psoriasis.

\section{Hands and Feet}

Distal Interphalangeal Joints. - The findings in the $\stackrel{\mathbb{\Phi}}{\varrho}$ interphalangeal joints of the thumbs and big toes@ were analysed separately from other distal joints, $\rightarrow$ as their exact status was uncertain. There was no. significant difference in loss of space, erosion, or $\vec{\omega}$ expansion of the base of the terminal phalanx in these joints in psoriatic arthritis compared with $\frac{0}{0}$ rheumatoid arthritis. However, erosion of the interphalangeal joints of the thumbs, compared with erosion of the proximal interphalangeal joints, was commoner in psoriatic arthritis than in rheumatoid arthritis (Tables II and III).

In the distal joints of other fingers, erosion was more common in psoriatic arthritis than rheumatoidc arthritis (Table II). Changes in psoriatic arthritis (Figs 1 and 2, opposite) were usually more gross than $\vec{\circ}$ in rheumatoid arthritis. In only one patient witho psoriatic arthritis was arthritis limited to the disegljoints. The distal joints of the toes were involved more often $(P<0.01)$ in psoriatic arthritis thei uncomplicated or coincidental rheumatoid art $\overrightarrow{\mathrm{h}}-\bar{\partial}$ ritis.

Terminal Phalanges.-Changes in the terminal phalanx, although uncommon, were characteristic $\overrightarrow{\overrightarrow{0}}$ of psoriatic arthritis. They included cystic areas 3 and irregularity of the tip extending to the shaft, progressing to whittling away of the bone (Fig. 2)

TABLE II

RADIOGRAPHIC FINDINGS IN THE DISTAL INTERPHALANGEAL JOINTS OF THE FINGERS AND TOES

\begin{tabular}{|c|c|c|c|c|}
\hline Digit & Finding & $\begin{array}{l}\text { Psoriatic Arthritis } \\
\text { (103 patients) }\end{array}$ & $\begin{array}{l}\text { Rheumatoid Arthritis } \\
\text { (91 patients) }\end{array}$ & $\begin{array}{c}\text { Coincidental } \\
\text { Rheumatoid Arthritis } \\
\text { (18 patients) }\end{array}$ \\
\hline \multirow{4}{*}{ Thumb } & Loss of space & 17 & 10 & - \\
\hline & Erosion & 18 & 11 & 2 \\
\hline & Expanded base of T.P. & 12 & 3 & - \\
\hline & Ankylosis & 2 & - & 一 \\
\hline \multirow{4}{*}{ Second to Fifth Fingers } & Loss of space & 18 & 16 & 2 \\
\hline & Erosion & 23 & 11 & 3 \\
\hline & Expanded base of T.P. & 12 & 4 & 1 \\
\hline & Ankylosis & 3 & - & - \\
\hline Big Toe & Erosion & 18 & 3 & 1 \\
\hline Second to Fifth Toes & Erosion & 18 & 2 & 2 \\
\hline
\end{tabular}


TABLE III

RADIOGRAPHIC FINDINGS IN THE PROXIMAL INTERPHALANGEAL JOINTS OF. THE FINGERS AND TOES

\begin{tabular}{|c|c|c|c|c|}
\hline Site & Finding & $\begin{array}{l}\text { Psoriatic Arthritis } \\
\text { (103 patients) }\end{array}$ & $\begin{array}{l}\text { Rheumatoid Arthritis } \\
\text { (91 patients) }\end{array}$ & $\begin{array}{l}\text { Coincidental } \\
\text { Rheumatoid Arthritis } \\
\text { (18 patients) }\end{array}$ \\
\hline \multirow{4}{*}{ Hands } & Loss of space & 17 & 38 & 8 \\
\hline & Erosions & 30 & 45 & 8 \\
\hline & Cysts & 6 & 7 & 1 \\
\hline & Ankylosis & 1 & 4 & 1 \\
\hline Feet & Erosions & 23 & 15 & 3 \\
\hline
\end{tabular}

In the fingers cystic changes occurred in four patients, whittling in two. In the toes, whittling occurred in five and irregularity of the shaft in fifteen, but in only three patients with rheumatoid arthritis $(P<0.01)$. Whittling away of the bone occurred only in association with nail changes. Radiographs of the hands and feet of fourteen

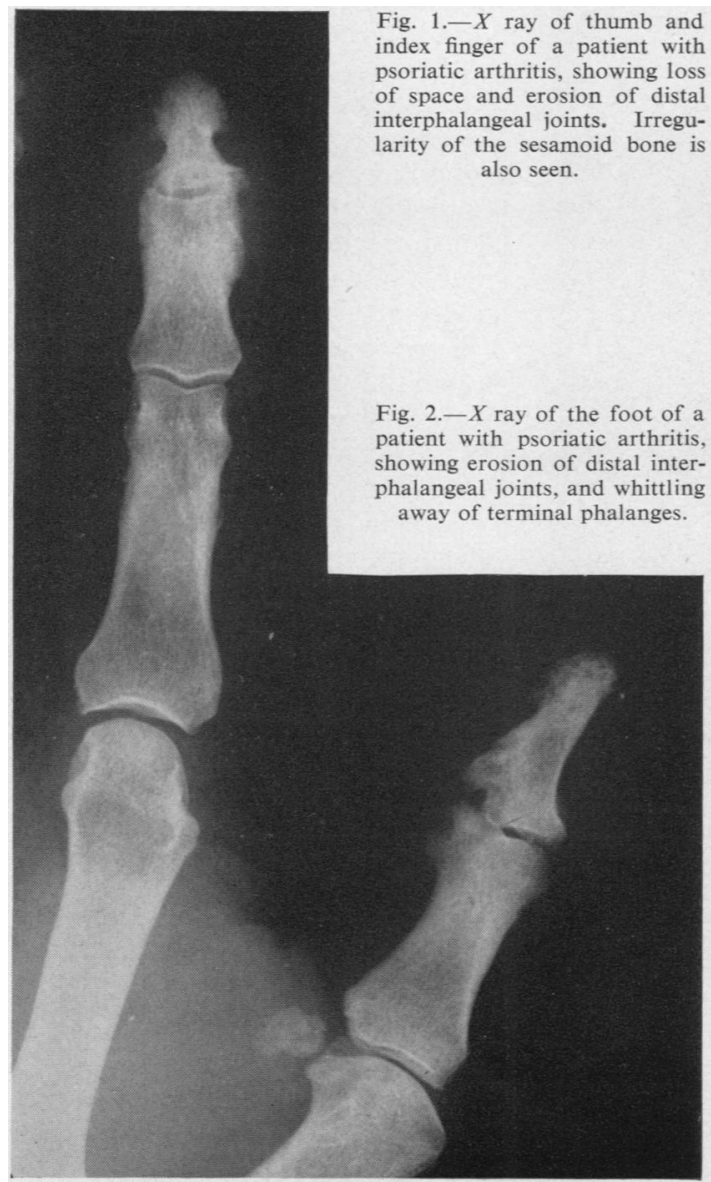

patients with severe psoriatic nail changes and no clinical evidence of arthritis were therefore taken, but no changes in the terminal phalanges were seen.

Opacities in the terminal phalanges of the fingers were noted in fifteen patients with psoriatic arthritis and in thirteen with rheumatoid arthritis. In the 
rheumatoid group the changes were noted only in women (a sex difference of probable significance, $P<0.05)$. In psoriatic arthritis they occurred in twelve women and three men.

Other Digital Joints.-In the proximal interphalangeal joints of the toes, only the erosions were read since loss of space is difficult to ascertain in these joints. There was no significant difference between the groups, although involvement was commoner in psoriatic arthritis (Table III, and Fig. 3).

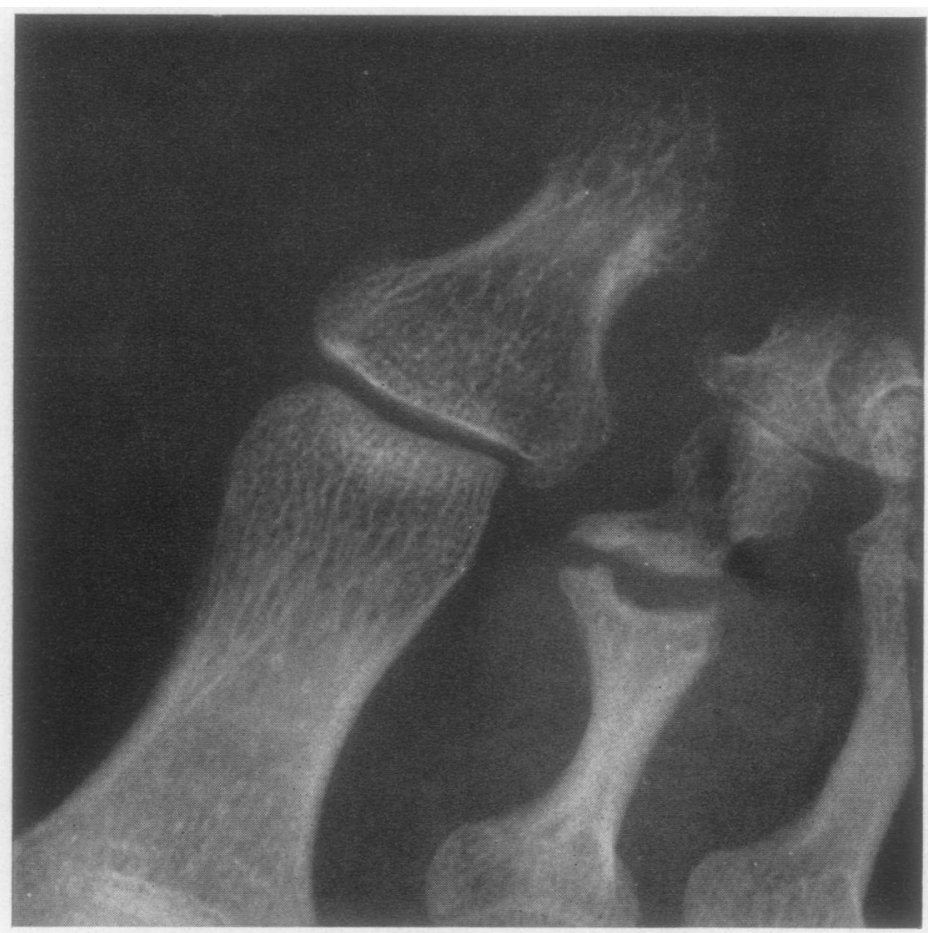

Fig. 3. $-X$ ray of the toes in a patient with psoriatic arthritis, showing erosion of proximal interphalangeal joint.

TABLE IV

RADIOGRAPHIC FINDINGS IN THE METACARPO- AND METATARSO-PHALANGEAL JOINTS

\begin{tabular}{|c|c|c|c|c|}
\hline Site & Finding & $\begin{array}{l}\text { Psoriatic Arthritis } \\
\text { (103 patients) }\end{array}$ & $\begin{array}{l}\text { Rheumatoid Arthritis } \\
\text { (91 patients) }\end{array}$ & $\begin{array}{l}\text { Coincidental } \\
\text { Rheumatoid Arthritis } \\
\text { (18 patients) }\end{array}$ \\
\hline \multirow{4}{*}{ Hands } & Loss of space & 25 & 57 & 7 \\
\hline & Erosions & 24 & 57 & 8 \\
\hline & Cysts & 3 & 9 & 2 \\
\hline & Deformity & 10 & 19 & 6 \\
\hline \multirow{4}{*}{ Feet } & Loss of space & 15 & 49 & 10 \\
\hline & Erosions & 24 & 62 & 10 \\
\hline & Cysts & 8 & 11 & 4 \\
\hline & Deformity & 17 & 35 & 2 \\
\hline
\end{tabular}
Loss of space and erosion in the proximal inter- $-\frac{\vec{\Phi}}{\mathrm{D}}$
phalangeal joints of the fingers were more common $\frac{\overrightarrow{3}}{3}$ in rheumatoid arthritis than psoriatic arthritis $\square$ $(P<0.01)$. In the metacarpo-phalangeal and ${ }^{\circ}$. metatarso-phalangeal joints loss of space and $\overrightarrow{\vec{s}}$ erosions were commoner in rheumatoid arthritis? than psoriatic arthritis (Table IV, $P<0.01)$. There $\frac{-}{-}$ features were significantly commoner $(P<0.01)$ in $\frac{\bar{\omega}}{\bar{c}}$ the metatarso-phalangeal joints of patients with $\overrightarrow{\widetilde{\Phi}}$ coincidental rheumatoid arthritis than with psoriatic arthritis. Deformity of the meta-e carpo-phalangeal joints was com- $\overrightarrow{0}$ moner in uncomplicated and coinci- $-\overrightarrow{-}$ dental rheumatoid arthritis $(P<0.01 \vec{\omega}$ and $<0.05)$.

Wrists.-In the carpus, loss of space and erosion were commonero $(P<0.01)$ in uncomplicated and ${ }^{N}$ coincidental rheumatoid arthritis (Table V, opposite). Ankylosis waso significantly commoner in uncom- plicated rheumatoid arthritis $\left(P_{C}\right.$ $<0.01)$.

The radio-navicular joint (Table $\mathrm{V}$ ) similarly showed loss of space andब erosion more often in uncomplicatêd. and coincidental rheumatoid arthrits: $(P<0.01)$, and ankylosis significa ly more often in uncomplicated rheümatoid arthritis $(P<0 \cdot 02)$.

We were unable to confirm the sug- $-\frac{\mathrm{Q}}{\mathbb{Q}}$ gestion that there is a relative sparing $\overrightarrow{\vec{A}}$ of the metacarpo-phalangeal joints 3 when the wrists are involved in psoriatic arthritis. The metacarpo-o phalangeal joints were usually involved to a greater degree than the wrists in rheumatoid arthritis ando psoriatic arthritis. In only six psori 
TABLE V

RADIOGRAPHIC APPEARANCES IN THE WRISTS

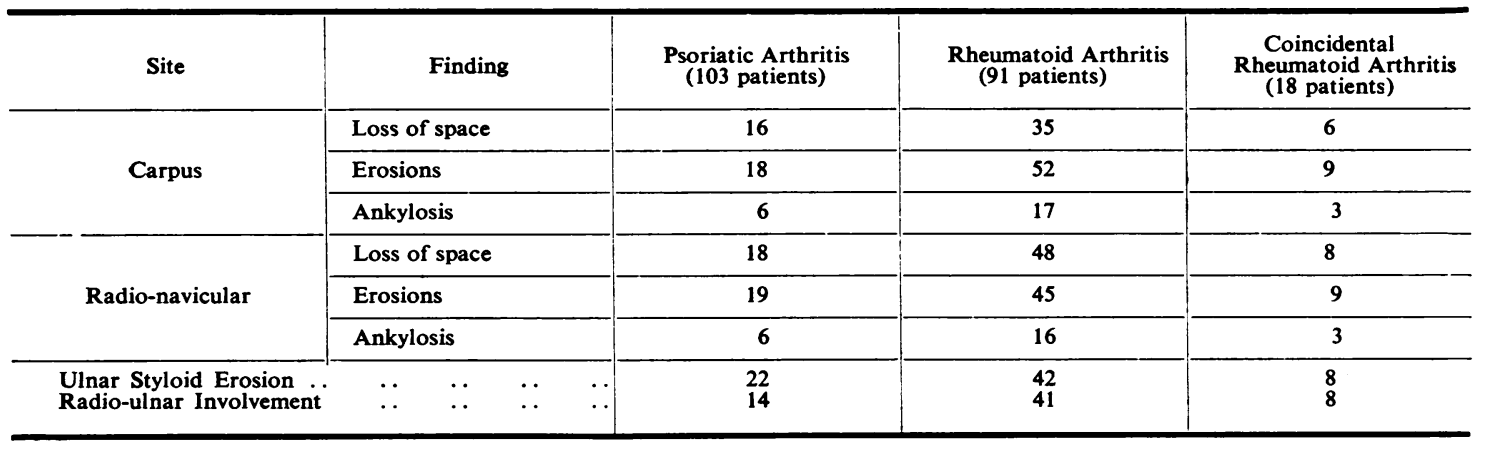

TABLE VI

DEGREE OF INVOLVEMENT OF METACARPOPHALANGEAL JOINTS (M.P.) and WRISTS AND RELATIVE FREQUENCY OF INVOLVEMENT OF RADIO-ULNAR AND RADIO-NAVICULAR JOINTS

\begin{tabular}{|c|c|c|c|c|c|c|c|c|c|}
\hline \multicolumn{7}{|c|}{ Degree of Joint Involvement } & \multirow{2}{*}{$\begin{array}{c}\begin{array}{c}\text { Psoriatic Arthritis } \\
\text { (103 patients) }\end{array} \\
19 \\
6 \\
12 \\
66\end{array}$} & \multirow{2}{*}{$\begin{array}{c}\begin{array}{c}\text { Rheumatoid Arthritis } \\
\text { (91 patients) }\end{array} \\
28 \\
12 \\
31 \\
20\end{array}$} & \multirow{2}{*}{$\begin{array}{c}\begin{array}{c}\text { Coincidental } \\
\text { Rheumatoid Arthritis } \\
\text { (18 patients) }\end{array} \\
2 \\
2 \\
6 \\
8\end{array}$} \\
\hline $\begin{array}{l}\text { M.P. > Wrists } \\
\text { Wrists > M.P. } \\
\text { M.P. = Wrists } \\
\text { Neither Involved }\end{array}$ & $\begin{array}{l}\cdots \\
\cdots \\
\cdots\end{array}$ & $\begin{array}{l}\ddot{ } \\
\ddot{*} \\
\cdots\end{array}$ & $\begin{array}{l}\cdots \\
\cdots \\
\cdots\end{array}$ & $\begin{array}{l}\cdots \\
\ddot{*} \\
\cdots\end{array}$ & $\begin{array}{l}\cdots \\
\cdots \\
\cdots\end{array}$ & $\begin{array}{l}\cdots \\
\cdots \\
\cdots \\
\cdots\end{array}$ & & & \\
\hline $\begin{array}{l}\text { Radio-ulnar On } \\
\text { Radio-navicular } \\
\text { Both .. } \\
\text { Neither } \quad \text {.. }\end{array}$ & $\begin{array}{l}\text { nìy } \\
\cdots \\
\cdots\end{array}$ & $\begin{array}{l}\ddot{ } \\
\cdots \\
\cdots\end{array}$ & $\begin{array}{l}\cdots \\
\cdots \\
\cdots\end{array}$ & $\begin{array}{l}\cdots \\
\cdots \\
\cdots\end{array}$ & $\begin{array}{l}\ddot{*} \\
\ddot{*} \\
\ddot{*}\end{array}$ & $\begin{array}{l}\cdots \\
\cdots \\
\cdots \\
\cdots\end{array}$ & $\begin{array}{r}3 \\
7 \\
12 \\
81\end{array}$ & $\begin{array}{r}4 \\
17 \\
33 \\
37\end{array}$ & $\begin{array}{l}1 \\
1 \\
7 \\
9\end{array}$ \\
\hline
\end{tabular}

atic patients was the reverse true (Table VI).

The radio-ulnar joint was involved more often in uncomplicated and coincidental rheumatoid arthritis $(P<0.01)$, but it was not found that where the wrists were involved it was the radio-ulnar rather than the radio-navicular joint which was affected in psoriatic arthritis (Table VI). The ulnar styloid process frequently showed erosion in all groups (Table V), but was more often involved in uncomplicated and coincidental rheumatoid arthritis $(P<0.01)$. It was of interest that in ten patients with rheumatoid arthritis the ulnar styloid process was eroded without evident damage of the radionavicular joint. Involvement of this process is a useful sign of rheumatoid arthritis.

\section{Sacro-iliac Joints}

The radiographic findings in the sacro-iliac joints of the present series are shown in Table VII.

TABLE VII

RADIOGRAPHIC APPEARANCES IN SACRO-ILIAC JOINTS

\begin{tabular}{|c|c|c|c|}
\hline Finding & $\begin{array}{c}\text { Psoriatic } \\
\text { Arthritis } \\
\text { (99 patients) }\end{array}$ & $\begin{array}{l}\text { Rheumatoid } \\
\text { Arthritis } \\
\text { (90 patients) }\end{array}$ & $\begin{array}{c}\text { Coincidental } \\
\text { Rheumatoid } \\
\text { Arthritis } \\
\text { (18 patients) }\end{array}$ \\
\hline $\begin{array}{l}\text { Erosion } \\
\text { Sclerosis } \\
\text { Ankylosis }\end{array}$ & $\begin{array}{r}19 \\
11 \\
8\end{array}$ & $\begin{array}{l}5 \\
4 \\
1\end{array}$ & $\begin{array}{l}1 \\
1 \\
1\end{array}$ \\
\hline
\end{tabular}

Erosion was more common in psoriatic arthritis $(P<0 \cdot 01)$. Sclerosis and ankylosis (Fig. 4, overleaf) were also more common in psoriatic arthritis. In only one patient with uncomplicated rheumatoid arthritis did ankylosis occur, and this was present on one side only. Unilateral changes occurred in six of the 29 patients with psoriatic arthritis who had sacro-iliac involvement. The proportion of unilateral changes were not significantly different in rheumatoid arthritis.

\section{Other Features}

A severely destructive arthritis occurred in four patients with psoriatic arthritis. They showed classical arthritis mutilans with main en lorgnette (opera-glass hand) and a similar condition in the feet. There was "melting away" of the metatarsal and metacarpal heads and phalanges (Figs 5 and 6, overleaf). In all four the sacro-iliac joints were also involved.

Some authors have commented on a lack of bone porosis despite destruction, but in the present series this feature was only noted in three patients with psoriatic arthritis and one with rheumatoid arthritis. A generalized osteoporosis, however, was found more commonly in the hands and feet of patients with uncomplicated rheumatoid arthritis. 


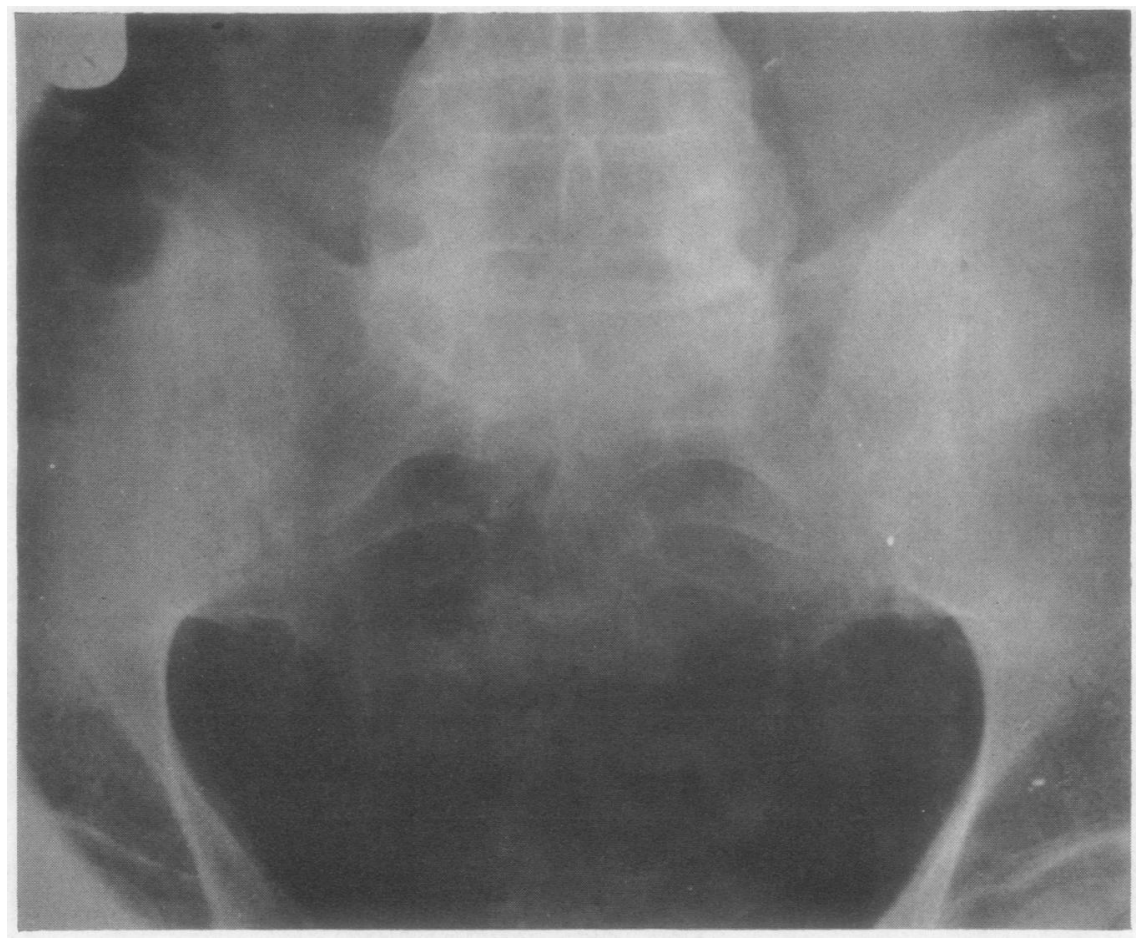

Fig. 4. $-X$ ray of the sacro-iliac joints of a patient with psoriatic arthritis, showing ankylosis.

Only in the metatarso-phalangeal joints of patients with psoriatic arthritis was asymmetrical involvement found. Such asymmetry was seen in 42 per cent. of psoriatic patients with these joints involved compared with 18 per cent. of rheumatoid patients $(P<0.02)$.

DEFINITION

The absence until recent years of a laboratory test which would distinguish between rheumatoid arthritis and psoriatic arthritis has made analysis of the clinical and radiographic features of psoriatic arthritis difficult. The advent of the Rose-Waaler differential agglutination test (D.A.T.) seems to have provided a solution, for this detects a specific abnormality in the serum of about 80 per cent. of patients with rheumatoid arthritis (Ball, 1952).

Of 121 patients with psoriasis and erosive arthritis, eighteen had a positive D.A.T. Their clinical and radiographic picture differed in no way from that of uncomplicated rheumatoid arthritis, and they appear to be examples of coincidental psoriasis and rheumatoid arthritis, an association one would expect to find in an unselected series since both diseases are common. This view is strengthened by the finding in these patients of subcutaneous nodules, often regarded as the most characteristico lesion of rheumatoid arthritis (Bauer, 1939; Bennett, 1943), in a proportion similar to that seen in patients with uncomplicated rheumatoid arthritis, whilst in psoriatic patients with a negative D.A.T. they were absent. In our present state of knowledge it wouldo seem wisest to designate as "psoriatic arthritis" the 3 . erosive arthritis in psoriatic patients with a negative D.A.T. The finding of a group of patients with coincidental rheumatoid arthritis in a large un-o selected series is important, not only because it? confirms what would be anticipated if psoriatico arthritis is a separate entity, but also because it provides a group for comparative purposes. It is interesting to note, therefore, that, although the group was usually too small to permit statisticaln comparisons, the differences between uncomplicatedo rheumatoid arthritis and psoriatic arthritis were similar in the patients with coincidental rheumatoid arthritis. Since some patients with psoriatic arth $\stackrel{\infty}{\rightarrow}$ ritis when examined individually have an arthritis very similar to rheumatoid arthritis, and arthritiso may precede the psoriasis by many years, it has 


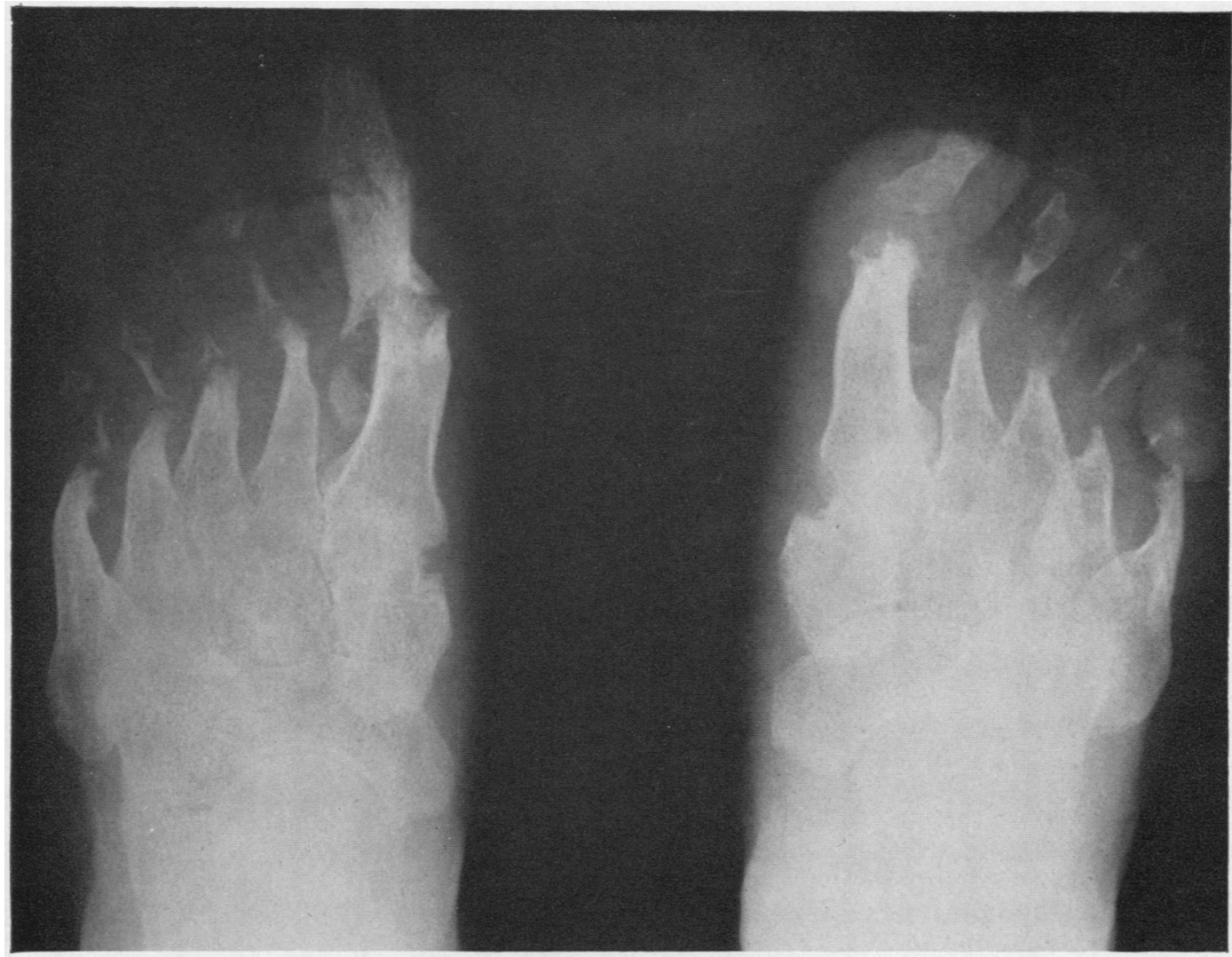

Fig. 5.- $X$ ray of the feet of a man with psoriatic arthritis, showing tapering of mctatarsal bones and destruction of phalanges.

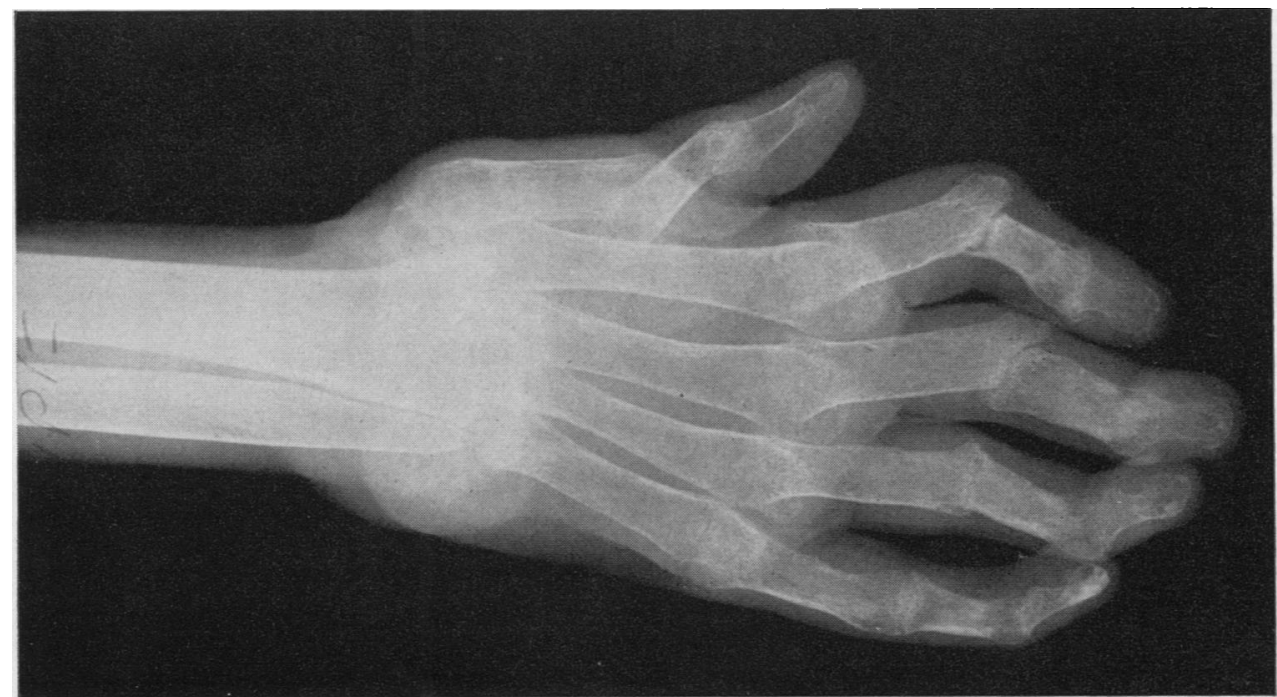

Fig. 6.- $X$ ray of the hand of a man with psoriatic arthritis, showing destructive changes of all joints of hand and wrist. Clinically the patient showed mains en lorgnette. 
been suggested (Wright, 1956b) that some patients with apparently uncomplicated rheumatoid arthritis but a negative differential agglutination test are destined to develop psoriasis. This has since been observed (Dixon, 1958), and strengthens the suggestion that psoriatic arthritis is a distinct entity.

\section{General Manifestations}

Radiographically, psoriatic arthritis was less severe than rheumatoid arthritis as evidenced by the diminished frequency of involvement of the proximal interphalangeal joints of the fingers, metacarpoand metatarso-phalangeal joints, carpus, radionavicular and radio-ulnar joints, and ulnar styloid process. Generalized osteoporosis was also less marked, particularly in the hands. However, arthritis mutilans with great destruction and melting away of the bones occurred in a few patients. It was of interest that the proximal interphalangeal joints of the toes were more often involved in psoriatic arthritis, in contrast to the analogous joints of the fingers. Asymmetrical involvement, to which attention has previously been drawn (Sherman, 1952), was confirmed radiographically in the metatarso-phalangeal joints.

There was no confirmation of the suggestions that, in patients with psoriatic arthritis when the wrists are involved, there is relative sparing of the metacarpo-phalangeal joints, that the radio-ulnar rather than the radio-navicular joints are involved (Sherman, 1952), or that there is a lack of osteoporosis despite destructive changes (Clemmeson and Arnsø, 1952; Fawcitt, 1950).

\section{Distal InTerphalangeal JoINTS}

Characteristic features of psoriatic arthritis included more frequent involvement of the distal interphalangeal joints, especially of the toes. This has been noted by other authors (Benedek, 1955; Golden, 1948; Popp and Addington, 1941 ; Sherman, 1952). In only one patient were such changes confined to these joints and there seems no justification for restricting the definition of psoriatic arthritis to those patients in whom they are so confined (Bauer, Bennett, and Zeller, 1941). Because of doubt whether to classify the interphalangeal joints of the thumbs as distal or proximal joints they were analysed separately. No significant difference was found between rheumatoid and psoriatic arthritis, but it was noted that in the latter the thumb joints were involved more often than the proximal interphalangeal joints as compared with rheumatoid arthritis.

Erosion of the tips of the terminal phalanges was a characteristic though uncommon feature of $\frac{\pi}{\frac{1}{2}}$ psoriatic arthritis, occurring more frequently in the feet. This feature occurred only in relation to nail changes. However, fourteen patients with severe nail involvement but without arthritis did not show such changes. Dense opacities in the terminal phalanges were found among patients with rheuma- 0 toid and psoriatic arthritis, and appeared not to be $\underline{\underline{\sigma}}$ related to the type of arthritis. They were signi- $\frac{\bar{D}}{\vec{Q}}$ ficantly more common in women.

\section{SACRo-ILIAC JoInTs}

Frequent mention has been made in the literature $\vec{\overrightarrow{ }}$ of the association of psoriasis and ankylosing $\omega_{\sigma}$ spondylitis (Clemmesen and Arnsø, 1952; Dawson@ and Tyson, 1938; Sterne and Schneider, 1953; Bouwens van der Boijen, 1939; Vilanova and Piñol, $O$ 1951), and the term "psoriasis spondylitica" has been? coined to describe such cases (Fletcher and Rose, $\vec{\omega}$ 1955). In the present unselected series, sacro-iliac ${ }_{\mathrm{O}}$ changes were found more commonly in patients with psoriatic arthritis than in the control group of $\vec{c}$ patients with rheumatoid arthritis, and erosion occurred in 19 per cent. All the psoriatic patients ${ }_{-}^{\Phi}$ with arthritis mutilans had sacro-iliac joint involve- $\vec{\oplus}$ ment.

It is interesting to speculate on the relationsh of Reiter's syndrome, in which there is a hight incidence of sacro-iliac joint disease, to psoriatic arthritis. We have now seen four patients, threeฏ of whom are not included in the present series, $\frac{2}{\mathbb{Q}}$ who in association with non-specific urethritis and $\overrightarrow{\vec{F}}$ arthritis developed keratoderma blennorrhagica $\frac{0}{3}$ which has since progressed to a typical psoriatic picture. In all four the sacro-iliac joints were involved. Histologically it is impossible to differentiate with certainty between pustular psoriasis and keratoderma blennorrhagica. It may well be $\overline{0}$ that there is a link between these two syndromes.

\section{Summary}

157 patients with psoriasis and various rheumatic complaints have been studied. In those with osteo-o arthritis, gout, rheumatic fever, and muscular rheumatism, there were no unusual clinical or radio- $N$ graphic features and their association seemed $N$ fortuitous.

121 patients with erosive arthritis were analysed in the light of the Rose-Waaler differential agglutination test and compared with 91 patients with uncomplicated rheumatoid arthritis and a positive test, who were matched by age, sex, and duration of ${ }_{7}$ arthritis. In all patients radiographs of the hands, feet, and sacro-iliac joints were taken. 
Eighteen patients with psoriasis and erosive arthritis had a positive differential agglutination test and were concluded to be examples of coincidental rheumatoid arthritis on clinical and radiographic grounds. 103 patients with psoriasis, erosive arthritis, and a negative differential agglutination test were thought to be examples of psoriatic arthritis. This arthritis was less severe than rheumatoid arthritis, and was characterized by distal interphalangeal joint involvement, erosion of the terminal phalanges, and a greater incidence of sacro-iliac joint changes.

I am indebted to Prof. S. J. Hartfall and Dr. J. T. Ingram for placing much clinical material at my disposal. Thanks are also due to Dr. A. G. S. Hill, Dr. D. S. Wilkinson, and Dr. R. Spalding Smith, with whom studies on the first patients were done, and to $\mathrm{Dr}$. J. Cowie for invaluable help.

\section{REFERENCES}

Alibert, J. L. (1822). "Précis théorique et pratique sur les maladies de la peau", 2nd ed. Caille and Ravier, Paris.

Avila, R., Pugh, D. G., Slocumb, C. H., and Winkelmann, R. K. (1960). Radiology, 75, 691.

Ball, J. (1952). Ann. rheum. Dis., 11, 97.

Bauer, W. (1939). New Engl. J. Med., 221, 524.

-, Bennett, G. A., and Zeller, J. W. (1941). Trans. Ass. Amer. Physcns, 56, 349.

Benedek, T. (1955). "Rheumatoid Arthritis and Psoriasis Vulgaris", p. 15. Edward, Ann Arbor, Mich.

Bennett, G. A. (1943). Ann. intern. Med., 19, 111.

Bourdillon, C. (1888). "Psoriasis et arthropathies." Thesis, Paris.

Brit. med. J. (1956). Leader, 1, 1157.

Brocq, L. (1910). Ann. Derm. Syph., series 5, 1, 156.

Carrier, J. W. (1958). Amer. J. Roentgenol., 79, 612.

Clemmesen, S., and Arnsø, E. (1952). In "Rheumatic Diseases: based on the Proceedings of the VII International Congress on Rheumatic Diseases", pp. 54-66. Saunders, Philadelphia.

Coste, F. (1958). Z. Rheumaforsch., 17, 90.

- Françon, J., Touraine, R., and Loyau, G. (1958). Rev. Rhum., 25, 75.

Dawson, M. H. (1937). Med. Clin. N. Amer., 21, 1807.

— and Tyson, T. L. (1938). Trans. Ass. Amer. Physcns, 53, 303.

de Forest, G. K., Mucci, M. B., and Boisvert, P. L. (1956). Amer. J. Med., 21, 897.

Dixon, A. St. J. (1958). Ann. rheum. Dis., 17, 252.

Epstein, E. (1939). Arch. Derm. Syph. (Chicago), $40,547$.

Fawcitt, J. (1950). Brit. J. Radiol., 23, 440.

Fletcher, E., and Rose, F. C. (1955). Lancet, 1, 695.

Golden, R. (1948). "Roentgenologic Diagnosis", vol. 2, p. 549. Williams and Wilkins, Baltimore.

Greenbury, C. L., Hill, A. G. S., Spalding Smith, R., and Good, M. S. (1956). Lancet, 1, 554.
Gribble, M. de G. (1955). Ann. rheum. Dis., 14, 198.

Heller, G., Kolodny, M. H., Lepow, I. H., Jacobson, A. S., Rivera, M. E., and Marks, G. H. (1955). J. Immunol., 74, 340.

Hench, P. S. (1927). Proc. Mayo Clin., 2, 89.

Jacobson, A. S., Kammerer, W. H., Wolf, J., Epstein, W. V., and Heller, G. (1956). Amer. J. Med., 20, 490.

Jeghers, H., and Robinson, L. J. (1937). J. Amer med. Ass., 108, 949.

Lane, C. G., and Crawford, G. M. (1937). Arch. Derm. Syph. (Chicago), 35, 1051.

Margolis, H. M. (1941). "Arthritis and Allied Disorders", p. 125. Hoeber, New York.

Meaney, T. F., and Hays, R. A. (1957). Radiology, 68, 403.

Popp, W. C., and Addington, E. A. (1941). Ibid., 36, 98.

Reed, W. B., and Becker, S. W. (1960). A.M.A. Arch. Derm., 81, 577.

Rose, H. M., Ragan, C., Pearce, E., and Lipman, M. O. (1948). Proc. Soc. exp. Biol. (N.Y.), 68, 1.

Sherman, M. S. (1952). J. Bone Jt Surg., 34A, 831.

Short, C. L., Bauer, W., and Reynolds, W. E. (1957). "Rheumatoid Arthritis", pp. 33-42. Harvard University Press, Cambridge, Mass.

Sterne, E. H., and Schneider, B. (1953). Ann. intern. Med., 38, 512.

Bouwens van der Boijen, G. (1939). "La rhumatisme psoriasique." Le François, Paris.

Vilanova, X., and Piñol, J. (1951). Rheumatism, 7, No. 1, p. 197.

Waaler, E. (1940). $\quad$ Acta path. microbiol. scand., 17, 172.

Wright, V. (1956). Ann. rheum. Dis., 15, 348.

(1957a). Brit. J. Radiol., 30, 113.

(1957b). Brit. J. Derm., 69, 1.

(1957c). Univ. Leeds med. J., 6, 98.

(1959). Amer. J. Med., $27,454$.

Ziff, M. (1957). J. chron. Dis., 5, 644.

Etude radiographique comparée de l'arthrite rhumatismale et de l'arthrite associée au psoriasis

\section{RÉSUMÉ}

On étudia 157 malades atteints de psoriasis et de diverses affections rhumatismales. Chez ceux atteints d'ostéoarthrite, goutte, rhumatisme articulaire aigu et rhumatisme musculaire il n'y avait pas de traits cliniques ou radiographiques extraordinaires et leur association paraissait fortuite.

A la lumière de la réaction d'agglutination différentielle de Rose-Waaler on analysa 121 cas d'arthrite érosive et on les compara à 91 cas d'arthrite rhumatismale non-compliquée, à réaction positive et aux âges, sexe et durée de l'arthrite assortis. Chez tous les malades on procéda à des radiographies des mains, pieds et des articulations sacro-iliaques.

Dix-huit malades atteints de psoriasis et d'arthrite érosive avaient une réaction d'agglutination différentielle positive et on les considéra, du point de vue clinique et radiologique, comme des exemples d'arthrite rhumatismale coincidente. Cent trois cas de psoriasis, d'arthrite érosive et de réaction d'agglutination différentielle négative furent considérés comme exemples d'arthrite 
psoriasique. Cette arthrite fut moins sévère que la rhumatismale et fut caractérisée par l'implication des articulations inter-phalangiennes distales, l'érosion des phalanges terminales et une plus grande fréquence de lésions articulaires sacro-iliaques.

\section{Estudio radiográfico comparativo de arthritis reumatoide} $y$ de arthritis asociada con soriasis

SUMARIO

Se estudiaron 157 enfermos con soriasis y padecimientos reumáticos diversos. En aquellos con osteoartritis, gota, reumatismo poliarticular agudo y reumatismo muscular, no existían rasgos clínicos o radiográficos peculiares y su asociación pareció ser fortuita.

A la luz de la reacción de aglutinación diferencial de
Rose-Waaler se analizaron 121 casos de artritis erosiva y se compararon con 91 casos de artritis reumatoide sin complicaciones, con reacción positiva, $y$ con edades, sexo y duración de la artritis correspondientes. En todos los enfermos se tomaron radiografías de las manos, pies y articulaciones sacro-iliacas.

En 18 enfermos con soriasis y artritis erosiva la reacción de aglutinación diferencial era positiva y estos casos fueron considerados, sobre bases clínicas y radiográficas, como ejemplos de artritis reumatoide coincidente. Ciento y tres enfermos con soriasis, artritis erosiva y reacción de aglutinación diferencial negativa fueron considerados como ejemplos de artritis soriásica. Dicha artritis era menos severa que la reumatoide y se caracterizaba por afectar la articulación interfalangiana distal, erosión de las falanges terminales y una mayor incidencia de lesiones articulares sacro-iliacas. 